Ann. Biol. anim. Bioch. Biophys., I966, 6 (3), 389-409.

\title{
CROISSANCE DES TISSUS DU RAT ET QUALITÉ DES PROTÉINES ALIMENTAIRES; INFLUENCE SUR LE NOMBRE ET LA TAILLE DES CELLULES
}

\author{
G. DURAND, G. FAUCONNEAU et Éliane PENOT \\ avec la collaboration technique de Noëlle BourgeAux \\ Laboratoire des Métabolismes, \\ Centre national de Recherches zootechniques, 78 -Jouy-en-Josas
}

SOMMAIRE

La croissance de la carcasse, de l'intestin grêle et du foie de rats nourris, les uns avec des protéines de mauvaise qualité (gluten de blé), les autres avec des protéines de bonne qualité (farine de hareng), a été étudiée en utilisant les tests suivants :

- mesure des variations de la teneur en acide désoxyribonucléique (DNA), dont la quantité est porportionnelle au nombre de noyaux, ou par extension au nombre de "cellules $n$;

- mesure des variations du rapport : poids frais/DNA, proportionnel au poids, donc à la «taille des cellules";

- mesure des variations de certains aspests de l'astivité cellulaire, exprimées par les variations des rapports acide ribonucléique (RNA)/DNA et protéines/DNA.

Il est montré que les cellules des tissus et organes des animaux carencés sont moins nombreuses, donc plus grandes, et généralement plus riches en protéines que celles des tissus et organes correspondants et de même poids, provenant d'animaux normaux.

Il apparaît également que, dans le cas des organes et tissus provenant des animaux carencés, l'augmentation du nombre des cellules est plus étalée dans le temps, et demeure plus longtemps le facteur prirripal de la croissance.

\section{INTRODUCTION}

Dans une précédente publication (DuRAND et al., r965 a), l'étude biochimique de la croissance de la " carcasse », de l'intestin grêle et du foie du rat avait été envisagée, en fonction de l'âge de l'animal, sous les deux aspects suivants : 
a) L'évolution du nombre et de la taille des cellules et l'infuence respective de chacun de ces deux facteurs sur la croissance. Nous avions expliqué en détail les raisons qui nous ont amenés à donner, par convention, au mot "cellule " la définition suivante : "ensemble d'un noyau et de la quantité moyenne de matière vivante qui lui est associée y compris le matériel interstitiel ». D'après cette définition, le nombre de cellules est donc égal au nombre de noyaux, et le rapport

$$
\frac{\text { Poids frais (d'un tissu ou d'un ensemble de tissus) }}{\text { Nombre de noyaux }}
$$

permet d'apprécier la " taille des cellules".

L'évolution du nombre de cellules d'un tissu ou organe est parallèle à celle de la quantité de DNA qu'il contient (BoIvin et VENDRELY, I948). L'évolution de la taille des cellules est donc parallèle à celle du rapport poids frais/DNA.

b) L'évolution de certains aspects de l'activité cellulaire, parmi lesquels la quantité d'acide ribonucléique et d'azote protéique par cellule: ces quantités varient comme les rapports RNA/DNA et protéines/DNA.

De plus, la croissance de la carcasse avait été envisagée quant à l'évolution de sa composition globale, c'est-à-dire des teneurs relatives en protéines $(N \times 6,25)$, eau, lipides et cendres. Les résultats ont permis de décrire, chez des rats de 3 à $\mathbf{I}$ / semaines, le type de croissance propre à chacune des parties étudiées et de préciser dans les trois cas les rôles respectifs de la multiplication et du grandissement cellulaires.

L'objet de la présente publication est l'étude de l'influence de la qualité des protéines alimentaires sur l'évolution des mêmes phénomènes au cours de la croissance, avec les critères ci-dessus définis. Elle concerne la croissance comparée de l'intestin grèle (sans séreuse), du foie et de la "carcasse " de rats, les uns soumis à un régime apportant des protéines de bonne qualité (farine de poisson de Norvège), les autres à un régime apportant des protéines de mauvaise qualité (gluten de blé). Nous entendons par " carcasse " l'ensemble du corps de l'animal, moins le foie, l'intestin grêle et le gros intestin (ce dernier est écarté et n'est soumis à aucune analyse).

\section{MATÉRIEL ET MÉTHODE}

\section{Matériel animal}

Onze lots de rats mâles Wistar ont été utilisés. La numérotation, le nombre d'animaux, l'âge et le poids vif moyen au moment de l'abattage, ainsi que le régime alimentaire auquel ils ont été soumis sont rassemblés dans le tableau I.

- Lot 1 : les animaux n'ont consommé que le lait maternel.

- Lot 2 : après le sevrage, les animaux ont reçu pendant une semaine un aliment équilibré à base de blé et de farine de poisson (1 8 p. Ioo de matières azotées), appelé " aliment standard "

- Lots $H\left(H_{1} \dot{a} H_{5}\right)$ : après la semaine d'adaptation, on a distribué aux animaux un régime semi-synthétique à 16 p. Ioo de matières azotées; celles-ci sont apportées exclusivement par de la farine de hareng de Norvège (régime H). Quoique cet aliment soit relativement pauvre en méthio- 
nine-cystine, le taux azoté utilisé est tel que tous les acides aminés indispensables sont apportés en quantité suffisante pour couvrir les besoins du rat (RANHOTRA et JoHnson, 1965; RogErs et HARPER, I965).

TABLEAU I

\begin{tabular}{|c|c|c|c|c|}
\hline $\begin{array}{l}\text { Numéro } \\
\text { du lot }\end{array}$ & $\begin{array}{l}\text { Age à l'abattage } \\
\text { (semaines) }\end{array}$ & $\begin{array}{l}\text { Poids à l'abattage } \\
(\mathrm{g})\end{array}$ & Régime & $\begin{array}{c}\text { Nombre } \\
\text { d'animaux }\end{array}$ \\
\hline $\begin{array}{l}1 \\
2\end{array}$ & $\begin{array}{l}3 \\
4\end{array}$ & $\begin{array}{l}39 \pm 2 \\
70 \pm 3\end{array}$ & $\begin{array}{l}\text { Lait maternel } \\
\text { Standard }\end{array}$ & $\begin{array}{l}15 \\
11\end{array}$ \\
\hline $\begin{array}{l}\mathrm{H}_{1} \\
\mathrm{H}_{2} \\
\mathrm{H}_{3} \\
\mathrm{H}_{4} \\
\mathrm{H}_{5}\end{array}$ & $\begin{array}{l}5 \\
7,5 \\
10 \\
17 \\
40\end{array}$ & $\begin{array}{l}106 \pm 5 \\
193 \pm 10 \\
282 \pm 14 \\
393 \pm 25 \\
487 \pm 30\end{array}$ & $\begin{array}{l}\text { Farine de Hareng } \\
\text { (régime H) }\end{array}$ & $\begin{array}{r}10 \\
8 \\
5 \\
6 \\
6\end{array}$ \\
\hline $\begin{array}{l}\mathrm{G}_{1} \\
\mathrm{G}_{2} \\
\mathrm{G}_{3} \\
\mathrm{G}_{4}\end{array}$ & $\begin{array}{l}7,5 \\
10 \\
17 \\
40\end{array}$ & $\begin{array}{l}106 \pm 5 \\
157 \pm 7 \\
205 \pm 10 \\
439 \pm 25\end{array}$ & $\begin{array}{l}\text { Gluten de blé } \\
\text { (régime } G \text { ) }\end{array}$ & $\begin{array}{l}9 \\
7 \\
7 \\
5\end{array}$ \\
\hline
\end{tabular}

La composition centésimale du régime est portée dans le tableau 2. A I $000 \mathrm{~g}$ du mélange sont ajoutés $500 \mathrm{ml}$ d'eau, de façon à obtenir une pâte fluide. L'aliment ainsi composé est distribué ad libitum.

- Lots $G\left(G_{1} \dot{a} G_{4}\right)$ : après la semaine d'adaptation, on a distribué aux animaux un régime iso-énergétique au précédent, et contenant la même quantité de matières azotées (I6 p. Ioo). Mais celles-ci sont apportées exclusivement par du gluten de blé (régime $G$ ).

\section{TABLEAU 2}

Composition centésimale des régimes alimentaires

\begin{tabular}{|c|c|c|}
\hline & Régime $\mathrm{H}$ & Régime $\mathrm{Gl}$ \\
\hline Farine de poisson de Norvège. & 22,0 & 一 \\
\hline Gluten de blé ............. & 二 & 20 \\
\hline Amidon de maïs. . & 42,5 & 44,5 \\
\hline Sucre cristallisé.......... & 21,5 & 21,5 \\
\hline Huile d'arachide (pression).$\ldots \ldots \ldots \ldots \ldots$. & 8 & 8 \\
\hline Agar-Agar $\ldots \ldots \ldots \ldots \ldots \ldots \ldots \ldots \ldots$ & 2 & 2 \\
\hline Mélange minéral (OSBORNE et MENDEL). & 3 & 3 \\
\hline Mélange vitaminique (HENRY et Rérat, 1963) & 1 & 1 \\
\hline
\end{tabular}
phane.

Le régime ne permet pas de couvrir en particulier les besoins du rat en lysine et en trypto-

La composition centésimale eng du mélange sec est rapportée dans le tableau 2. A I $000 \mathrm{~g}$ du mélange sont ajoutés $650 \mathrm{ml}$ d'eau ; l'aliment ainsi constitué est distribué ad libitum. 
a) Consonmation cmparie des animatix $H$ et (i.

La consommation quotidienne des animaux II en fonction de leur poids est portée sur la figure $\mathrm{I}$. I)e $9.5 \mathrm{~g}$ (matière sèche) pour des animaux pesant $70 \mathrm{~g}$. elle s'élève jusqu'à $20,5 \mathrm{~g}$ pour des animaux pesant $400 \mathrm{~g}$. La figure 2 a représente la courbe de consonmation relative des animaux $\mathrm{G}$ par rapport à celle des animaux II de même poids. On remarque qu'au moment de la mise au régime

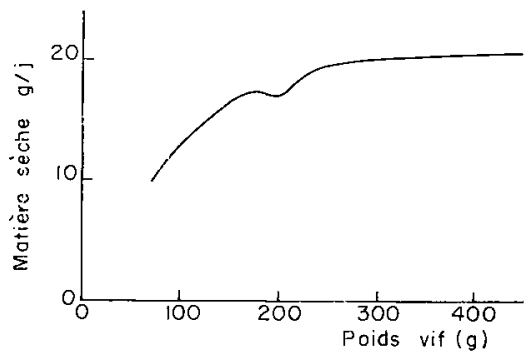

FIG. I. - Quantité d'aliments ingérée par les rals recevant de la farine de hareng (animanx 11 ), en jonction de leur poids rif

les premiers manifestent peu d'appétit pour l'aliment qui leur est distribué et ne consomment que 75 p. 100 de ce que consomment les seconds; puis ils semblent vouloir rattraper leur retard, ce qui correspond au premier sommet de la courbe. La consommation relative se stabilise ensuite à $85 \mathrm{p}$. roo quand les rats pèsent de 130 à $220 \mathrm{~g}$, augmente à nouveau ì partir de $220 \mathrm{~g}$ jusqu'à égaler celle des animaux $\mathrm{H}$ vers $290-300 \mathrm{~g}$.

$a$

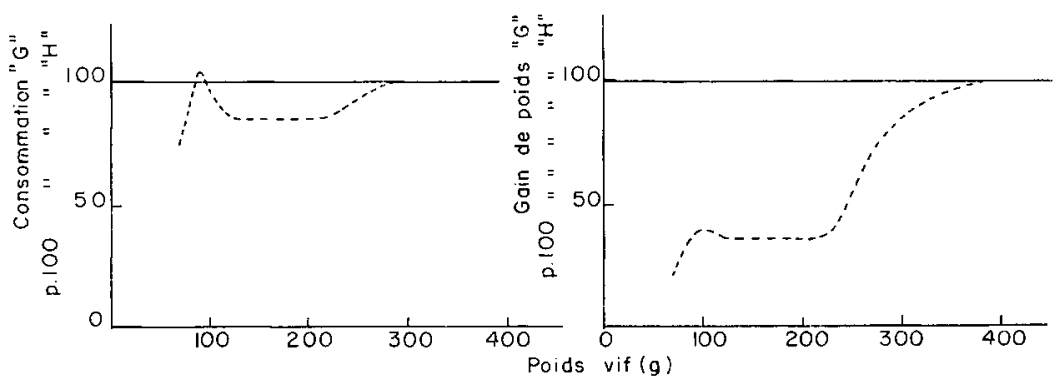

FIG. 2. - Consommation alinentaive (a) et croissance (b) relatives des rats recenant du gluten de blé (G) parrapport à celles des rats recevant de la farine de hareng $(\mathrm{H})$

\section{b) Croissance comparie des animaux $I /$ et $G$.}

La croissance des animaux $H$ est maximale (environ $5.5 \mathrm{~g}$ ) quand les animaux pèsent à peu près $200 \mathrm{~g}$. La figure $2 b$ représente la courbe de croissance relative des animaux G par rapport à celle des animaux de même pisids. A cours du prenier stade (de Ios à 220 g), quand la consommation relative des rats (; est de $85 \%$ \% 100, lear gain de poids (quotidien relatif eit de 37 p. roo. Quand les animaux $G$ attcignent 220 g, au moment oì leur appétit augmente, leur gain de poids relatif augmente lui aussi juspru'a atteindre pratiquement ros p. roo pour des animaux de $400 \mathrm{~g}$.

Il apparait done que, lorssue les animaux ( 3 at tejonent $220 \mathrm{~g}$, il y a un changement asse\% brusque dans leur hesoin en acidés amiaés indispensables : a patitir le ce stade, ils supportent de mieux en mieux un rérime p.uvre en lysine et en tryptophane : ceei apparaît sur les figures $3 a$ et $3 b$ où les coefficients d'utilisation pratiqu: d: l'azote et de l'énergie sont rapportés en fonction du poids vif. A partir de $300 \mathrm{~g}$, les animaux (; tendent à s'aligner sur les animaux $\mathrm{H}$; à partir de $400 \mathrm{~g}$ tous les animaux peuvent pratiquenent consommer indiféremment de la farine de poisson ou du gluten de blé, sans que leur vitesse de croissance s'en trouve affectée. Ceci n'est qu'une confirmation supplémentaire des conclusions de plusieurs auteurs et principalement de MitcinliL (I947) suivant lesquelles le besoin en lysine du rat adulte est très faible. 
Il est intéressant de considérer le moment du changement dans le besoin en acides aminés indispensables; celui-ci est-il dû au fait que les animaux aient atteint un certain poids $(220 \mathrm{~g})$ ou bien un certain âge (environ I 7 semaines)? La question serait aisément soluble en essayant parallèlement des protéines de qualités diverses, depuis l'œuf jusqu'à la zéine.

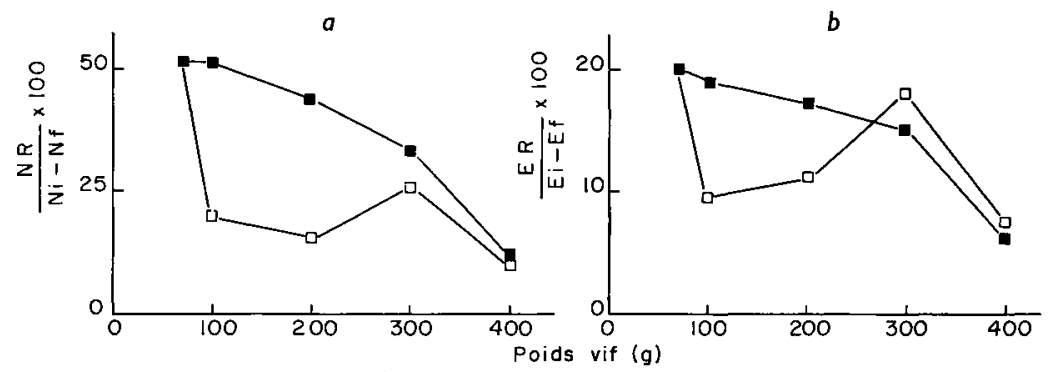

FIG. 3. - Évolution des coefficients de rélention :

a) de l'azole $\left(\frac{N \text { retenu }}{N \text { ingéré- } N \text { fécal }} \times 100\right)$

b) de l'énergie $\left(\frac{E \text { retenue }}{E \text { ingérée- } E \text { fécale }} \times 100\right)$

en fonction du poids vit de l'animal

- rats " Farine de Hareng " $\square$ rats "Gluten "

c) Aspect des animaux.

De 70 à $220 \mathrm{~g}$, le pelage des rats recevant le gluten est hérissé, de couleur blanc roux, et les régions de la peau exposées à la lumière (queue, extrémités des membres) sont couvertes d'érythèmes. Au-delà de $220 \mathrm{~g}$, ces symptômes disparaissent peu à peu, et les animaux reprennent un aspect normal.

\section{Méthodes analytiques}

Les méthodes d'abattage des animaux, les prélèvements des foies et des intestins grêles et toutes les opérations analytiques conduisant au dosage de l'azote (azote total et azote protéique), et des acides nucléiques (RNA et DNA) dans les organes et la carcasse ont déjà été décrites (DURAND et $a l ., 1965 a)$.

\section{RÉSULTATS}

Poids frais.

CARCASSE (tabl. 3 fig. $4 a$ à $4 d$ )

La carcasse, telle qu'elle a été définie, représente au sevrage 89,7 p. Ioo du poids vif, et seulement 82 p. roo chez des animaux de 70 g. Ceci est dû au développement important de l'intestin grêle, du cæcum et de son contenu après le sevrage. La phase d'allométrie positive de ces organes est suivie d'une phase d'allométrie négative, de sorte que la part de la carcasse dans le poids frais augmene à nouveau pour atteindre environ $92 \mathrm{p}$. Ioo chez des animaux dépassant $400 \mathrm{~g}$. Le régime ne semble pas avoir d'influence.

Composition globale.

Les résultats sont résumés dans le tableau 3 . La teneur des carcasses $\mathrm{G}$ en protéines est en général de Io à $20 \mathrm{p}$. Ioo inférieure à celle des carcasses $\mathrm{H}$ de même

Annales de Biologie animale. - Ig66. 
G. DURAND, G. FAUCONNEAU, E. PENOT

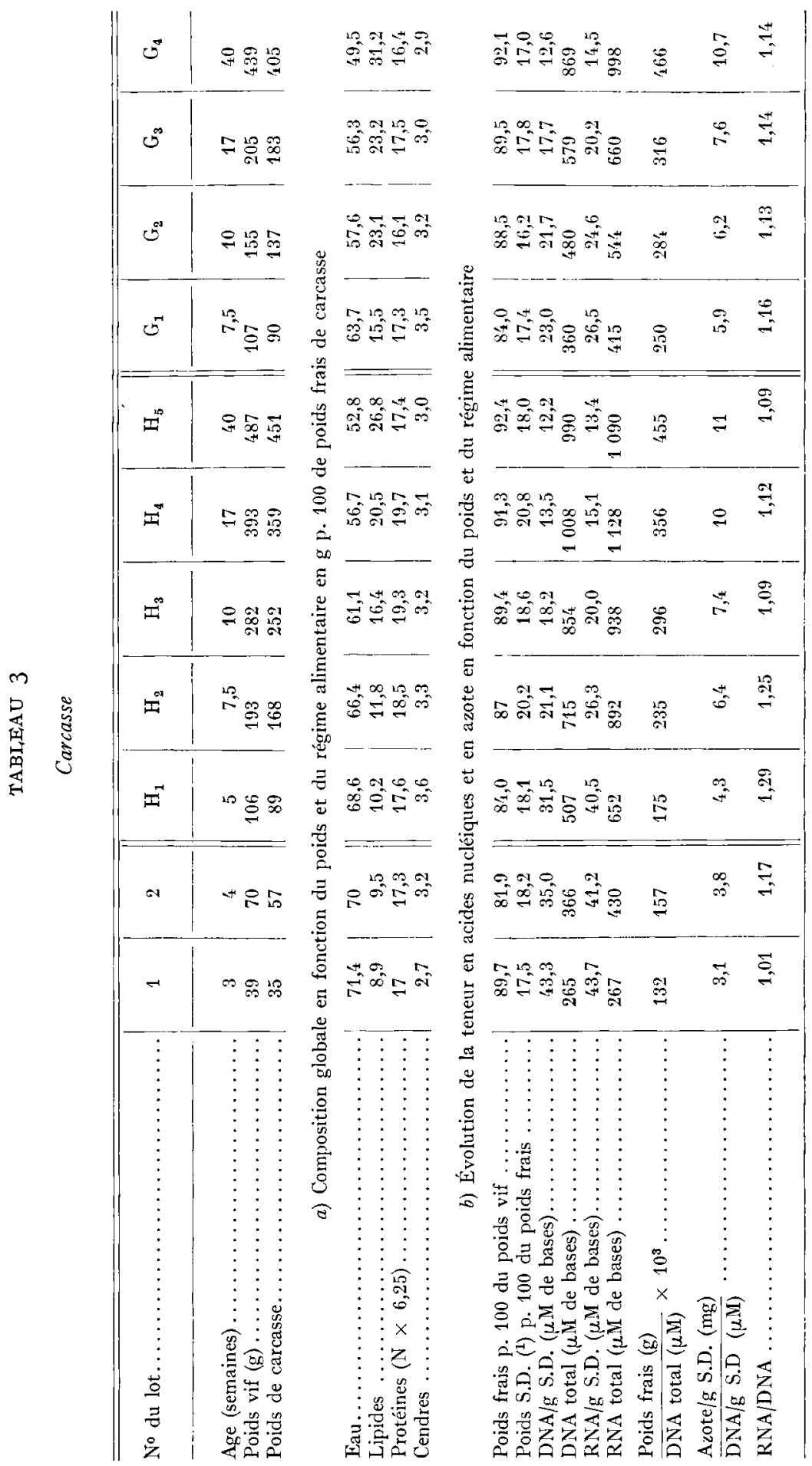


poids. Il y a un effet dépressif du gluten. Les teneurs en cendres ne semblent pas influencées par le régime. Les teneurs respectives en eau et en lipides sont modifiées : les animaux qui reçoivent les protéines de mauvaise qualité emmagasinent des quantités plus importantes de lipides et moins d'eau. Ainsi, les carcasses du lot $\mathrm{H}_{2}$ contiennent seulement II, 8 p. roo de lipides alors que les carcasses du lot $\mathrm{G}_{3}$, dont le poids est voisin, en contiennent 23,2 p. Ioo, soit pratiquement le double. Ces différences s'atténuent quand le poids des carcasses dépasse $400 \mathrm{~g}$.
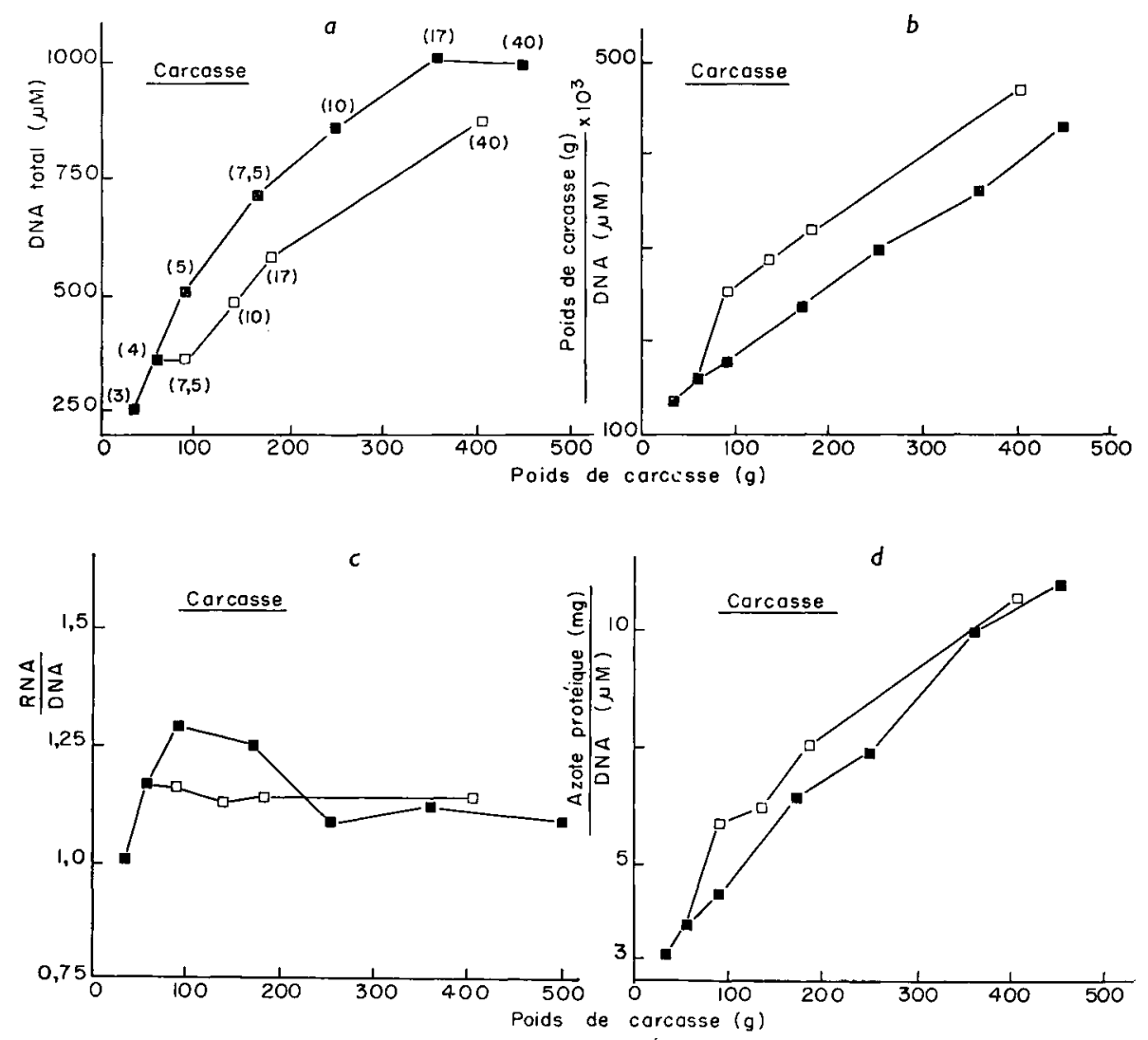

Fig. 4. - Carcasse. - Évolution :

a) du contenu total en DNA,

b) $d u$ rapport poids frais $/ D N A$,

c) du rapport $R N A / D N A$,

d) du rapport Azote protéiquelDNA

en forction du poids frais de la carcasse

- rats "Farine de Hareng " $\square$ rats "Gluten "

L'âge des animaux est noté entre paranthèses sur la figure $a$

Teneurs en DNA et rapport poids frais/DNA (fig. $4 a$ et 4 b).

L'étude de la teneur des carcasses $\mathrm{H}$ et $\mathrm{G}$, comparées à poids égal, en DNA et RNA a été déjà abordée dans une précédente publication (DURANd et $a l ., 1965 b$ ) ; il apparaît que, avec le régime $\mathrm{H}$, à partir du moment où les animaux pèsent $70 \mathrm{~g}$, 
la quantité de DNA augmente en fonction du poids de la carcasse suivant une courbe que l'on peut assimiler à un arc de l'hyperbole :

$$
y=\frac{\mathrm{I0}^{3} x}{0,74 x+107,5}
$$

où : $y$ est la quantité de DNA en micromoles (somme des bases én micromoles), $x$ le poids de la carcasse en grammes.

Lorsqu'on soumet les animaux au régime G, l'augmentation du DNA est provisoirement arrêtée, jusqu'à ce que le poids de la carcasse atteigne 90-Ioo g environ. Au-delà, le DNA augmente à nouveau en fonction du poids de la carcasse, suivant une courbe que l'on peut assimiler à un arc de l'hyperbole :

$$
y=\frac{\mathrm{IO}^{3} x}{0,68 x+\operatorname{IgI}, 0}
$$

Ia courbe (2) tend à se rapprocher de la courbe (I) sans toutefois pouvoir la rejoindre. Il faudrait, pour qu'il y ait intersection des deux courbes, que les carcasses atteignent un poids supérieur à I $300 \mathrm{~g}$, ce qui est absurde. Ainsi, dans nos conditions expérimentales, la teneur en DNA d'une carcasse G est inférieure de 30 à Io p.Ioo à celle d'une carcasse $\mathrm{H}$ de même poids.

Il résulte évidemment de ce qui précède que les rapports poids frais/DNA sont, dans l'un et l'autre cas, des fonctions approximativement linéaires du poids de carcasse et que le rapport poids frais/DNA G est toujours plus élevé.

\section{Activité cellulaive.}

RNA $/ D N A$ (fig. $4 \mathrm{c}$ ). - Partant de I, I7 pour des carcasses de $57 \mathrm{~g}$, le rapport RNA/DNAH est maximal quand les carcasses pèsent entre roo et $200 \mathrm{~g}$. Il est alors supérieur ou égal à $I, 29$. Il diminue ensuite et se stabilise autour de I, Io dès que les carcasses atteignent le poids de $250 \mathrm{~g}$. Le rapport RNA/DNA G présente une remarquable stabilité restant très voisin de $I, I_{5}$ pour des carcasses pesant de 57 à $400 \mathrm{~g}$.

Azote protéiquelDNA (fig. 4d). - Le rapport $\mathrm{H}$ augmente de 3, I à II quand. le poids de carcasse augmente de 35 à $45^{\circ} \mathrm{g}$. Le rapport $\mathrm{G}$ augmente très rapidement pendant la période de transition et devient supérieur de $30 \mathrm{p}$. IoO au rapport $\mathrm{H}$ correspondant. Cette différence s'atténue peu à peu et disparaît quand les carcasses atteignent le poids de $350 \mathrm{~g}$ environ.

\section{Poids frais.}

INTESTIN GRÊLE (tabl. 4, fig. $5 a$ à $5 d$ )

Celui-ci ne dépend que du poids vif des animaux; quel que soit le régime alimentaire, l'organe atteint $85-90 \mathrm{p}$. Ioo de son poids maximal (ro g environ) quand les animaux pèsent $200 \mathrm{~g}$. L,e poids de l'intestin grêle correspondant aux animaux $\mathrm{G}$ de $439 \mathrm{~g}$ (lot $\mathrm{G}_{4}$ ) est anormalement faible $(8,76 \mathrm{~g}$ ), comme des vérifications ultérieures, effectuées sur un grand nombre d'animaux, ont permis de le constater.

\section{Poids sec et dégraissé p. 100 du poids frais.}

La valeur de ce rapport décroît de II,4 à Io,5 durant la semaine qui suit la mise au régime $H$; elle augmente légèrement par la suite, et atteint II, 2 quand le poids de l'intestin est le plus élevé. 


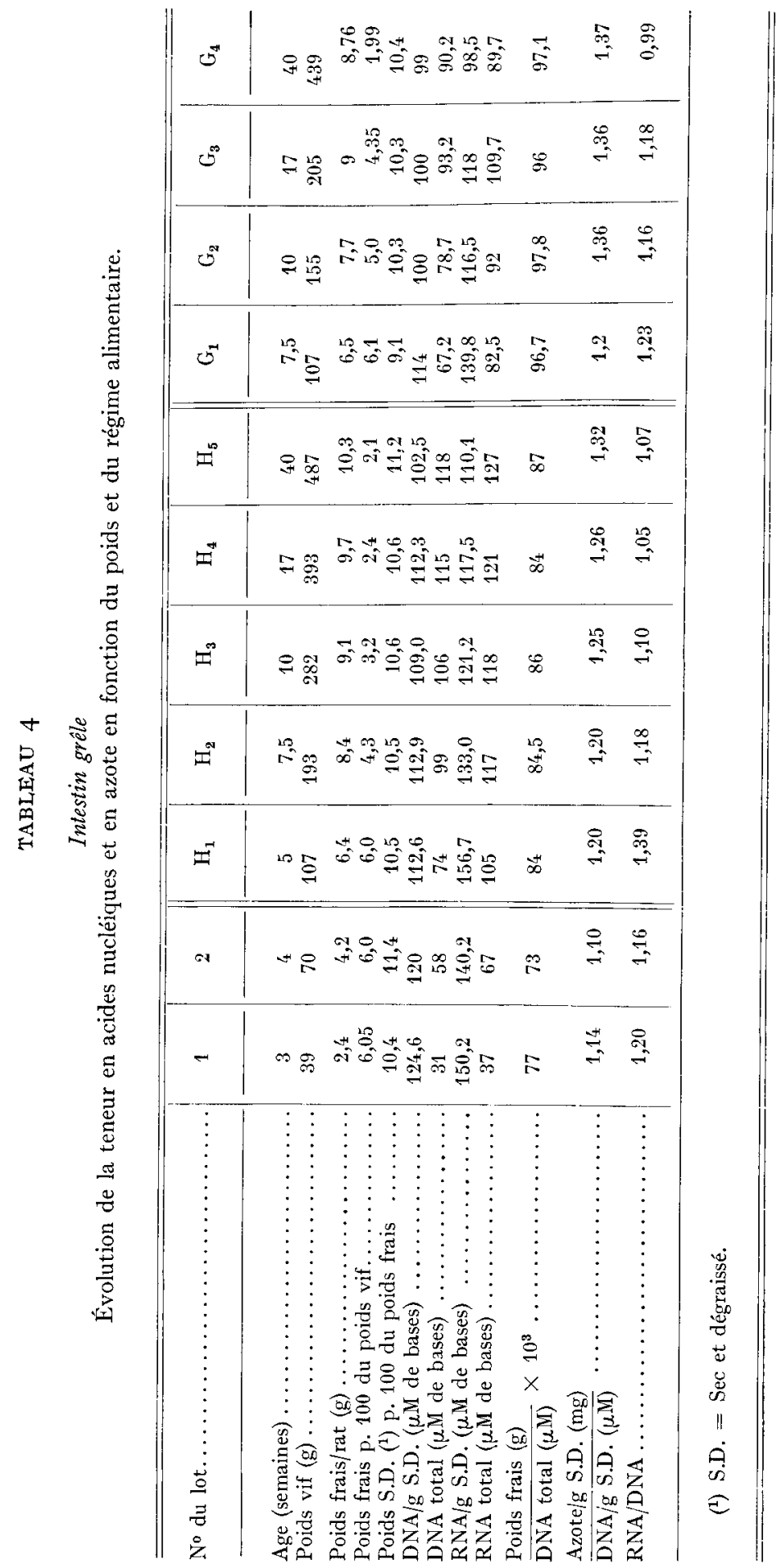


Dans le cas G, la valeur du rapport décroît de II,4 à 9 , I après la période qui suit la mise au régime; elle augmente à nouveau par la suite, et reste voisine de I0,3I0,4.
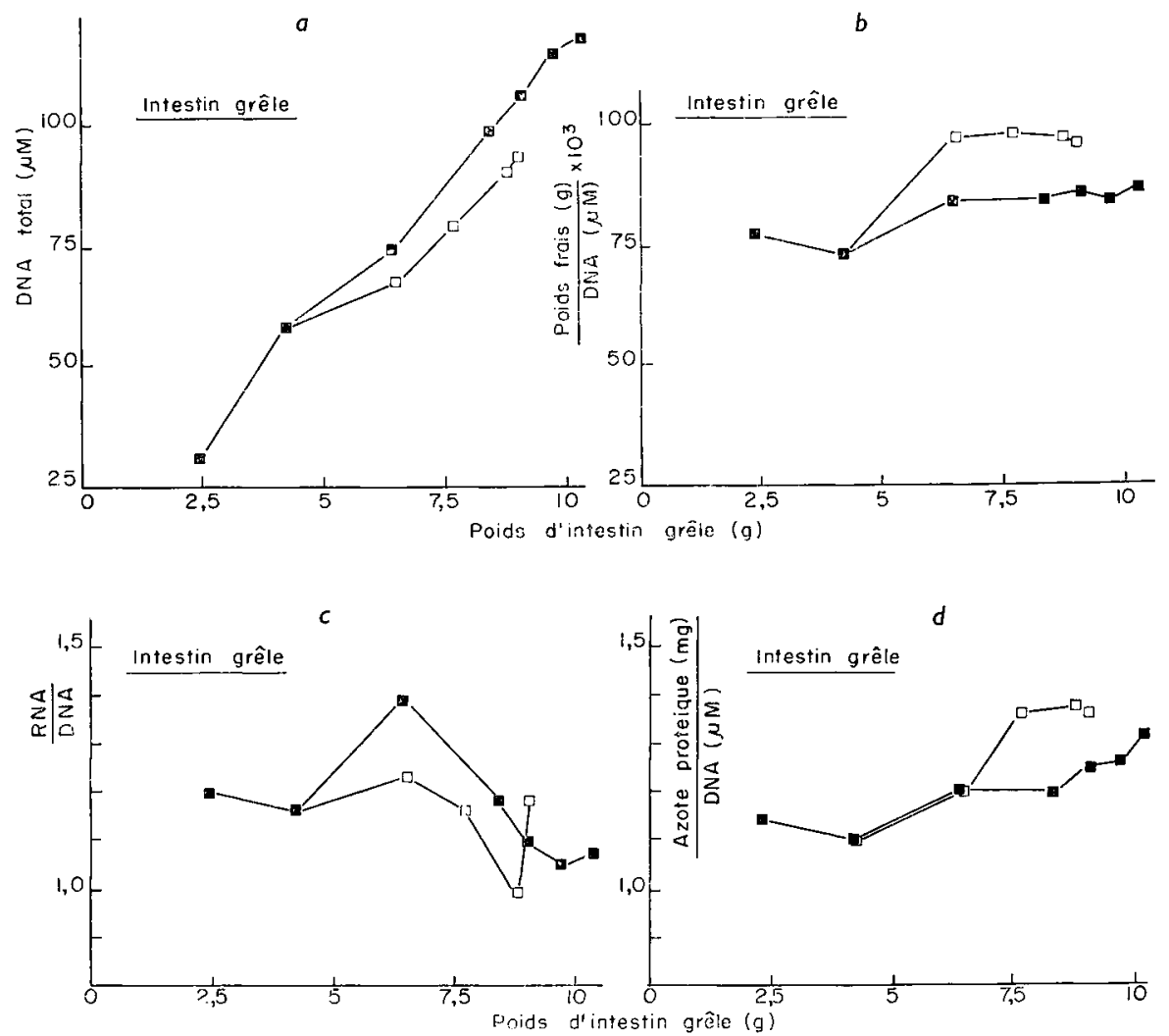

FIG. 5. - Intestin gréle. - Evolution en fonction du poids de l'organe:

a) du contcnu total en DNA,

b) du rapporl poids trais/DN.1,

c) du rapport RN.IDD. A ,

d) du rapport Asote protéique/DNA

- rats "Farine de Hareng" $\square$ rats "Gluten "

A poids égal d'organe, le rapport demeure donc légèrement plus faible quand les animaux reçoivent du gluten de blé.

Teneurs en DNA et rapport poids frais/DNA (fig. $5 a$ et $5 b$ ).

A poids égal d'organe, les intestins $\mathrm{G}$ contiennent moins de DNA que les intestins $H$ correspondants : 3,9 p. Ioo en moins pour des organes de $5 \mathrm{~g}$, I2,5 p. Ioo en moins pour des organes de $9 \mathrm{~g}$ et au-dessus. I1 s'ensuit évidemment que la valeur du rapport poids frais/DNA est plus grande dans le cas G. Mais dans les deux cas, elle est remarquablement peu variable dès que les organes ont atteint le poids de $6,5 \mathrm{~g}$, oscillant autour de $85 \times \mathrm{IO}^{3} \mathrm{~g} / \mu \mathrm{M}$ de bases DNA pour les intestins $\mathrm{H}$ et de $97 \times$ I0 ${ }^{3} \mathrm{~g} / \mathrm{MM}$ de basesDNA pour les intestins $\mathrm{G}$. 


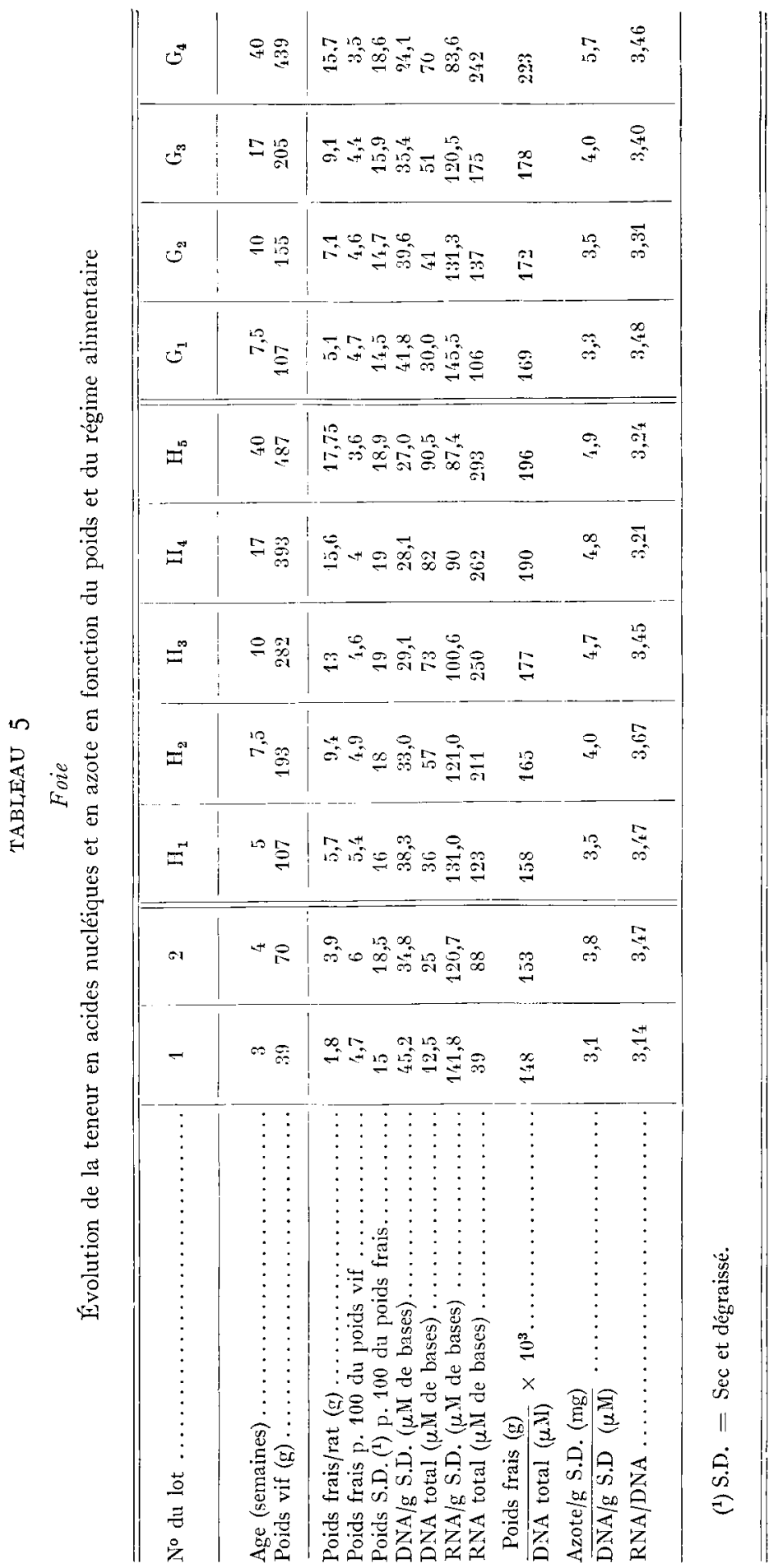




\section{Activité cellulaire.}

$R N A \mid D N A$ (fig. $5 c$ ). - Le rapport est plus faible pour les intestins grêles $\mathrm{G}$, tout au moins jusqu'à ce que le poids frais soit de $8,5 \mathrm{~g}$.

Azote protéique/DNA (fig. $5 d$ ). - Pour des intestins de 4 à $6,5 \mathrm{~g}$, le rapport est comparable dans les deux cas. Par la suite, le rapport $\mathrm{G}$ augmente fortement, de telle sorte que la teneur en azote de l'organe entier n'est pas éloignée de celle d'un organe $\mathrm{H}$ correspondant.

\section{Poids frais.}

$$
\text { FOIE (tabl. 5, fig. } 6 a \text { à } 6 d \text { ) }
$$

Quel que soit le régime alimentaire, le poids frais du foie augmente aussi longtemps que le poids vif de l'animal. Alors que le foie représente $4,7 \mathrm{p}$. Ioo du poids vif chez un rat de $39 \mathrm{~g}$, il représente encore $3,6 \mathrm{p}$. Ioo chez un rat de $450 \mathrm{~g}$ environ.
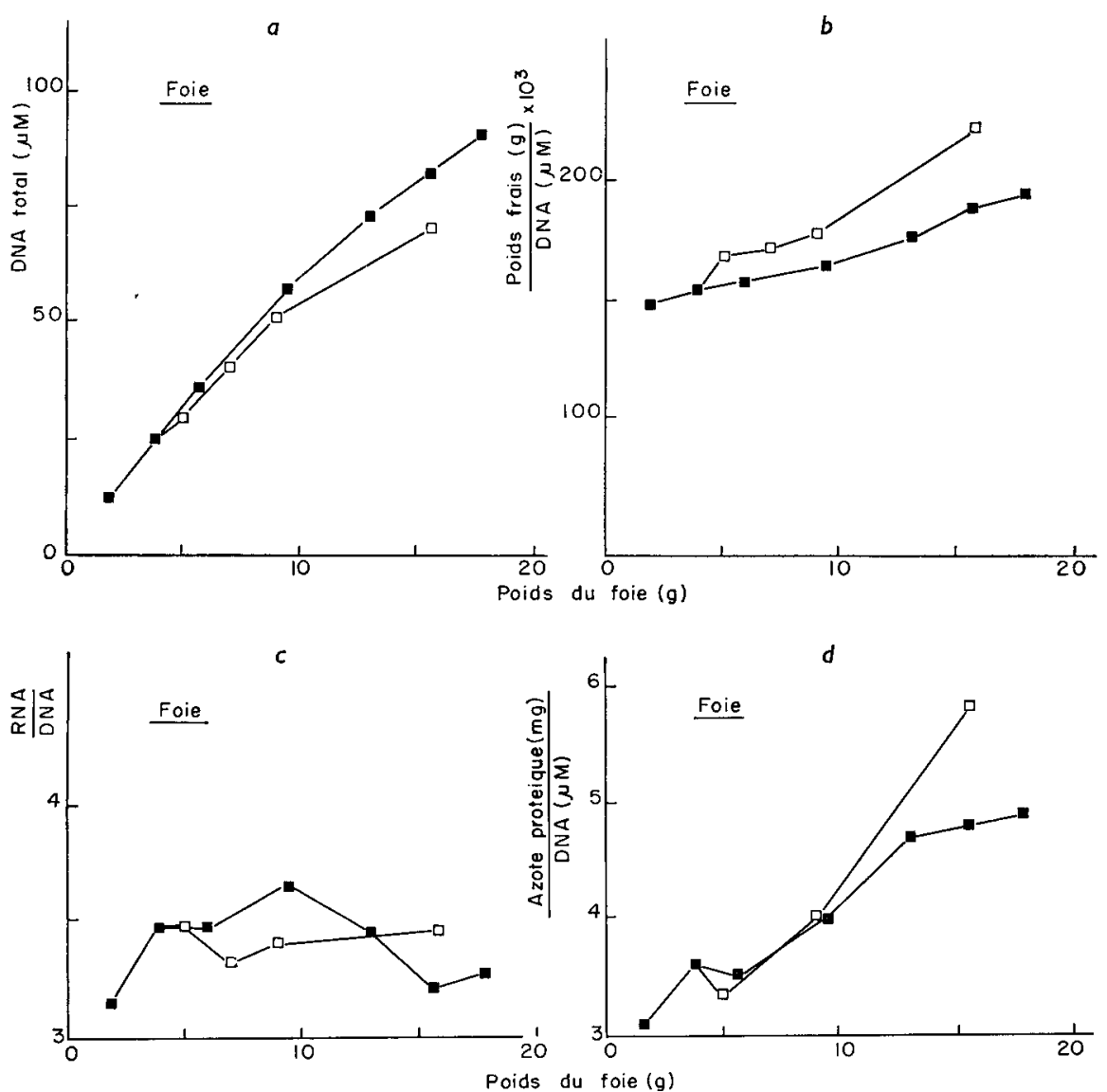

FIG. 6. - Foie - Evolution en fonction du poids de l'organe :
a) du contenu total en $D N A$,
b) du rapport poids frais/DNA,
c) du rapport RNAIDNA,
d) du rapport Azote protéique/DNA

- rats "Farine de Hareng " $\square$ rats " Gluten " 
A poids vif égal des animaux $\mathrm{H}$ et $\mathrm{G}$, le poids frais des foies $\mathrm{G}$ est plus faible que celui des foies $\mathrm{H}$ :

$$
\begin{array}{lll}
\text { de } \text { I0,5 } & \text { p. roo pour des animaux de ro5 } \mathrm{g} \\
\text { de } 8 & \text { p. Ioo pour des animaux de } 200 \mathrm{~g} \\
\text { de I2 } & \text { p. Ioo pour des animaux de } 440 \mathrm{~g}
\end{array}
$$

soit une infériorité moyenne de Io $\mathrm{p}$. roo.

Dans ce qui suit, les foies $\mathrm{H}$ et $\mathrm{G}$ seront comparés à poids frais égal.

Poids sec et dégraissé p. 100 du poids frais.

Celui-ci est plus faible dans le cas des foies $\mathrm{G}$ que dans le cas $\mathrm{H}$ : en effet, quand le poids des foies varie de 5 à $9 \mathrm{~g}$, ce rapport varie de $\mathrm{I} 6$ à I 8 dans le cas $H$, alors qu'il ne varie que de 14,5 à I $_{5}, 9$ dans le cas G. Au-delà, les foies G comblent peu à peu leur retard et le rapport atteint à peu près la même valeur [maximale pour des foies $\mathrm{G}$ de $\mathrm{I} 6 \mathrm{~g}$, soit environ $\mathrm{I} 9$.

Teneurs en $D N A$ et rapport poids frais/DNA (fig. 6 a et 6 b).

Ire DNA total des foies $\mathrm{G}$ est inférieur de $5 \mathrm{p}$. roo à celui des foies $\mathrm{H}$ pour des organes dont le poids augmente puisque l'écart s'accentue de 5 à I $_{5}$ p. roo quand le poids des foies augmente de Io à $16 \mathrm{~g}$. Le rapport poids frais/DNA est donc plus élevé dans le cas $\mathrm{G}$.

\section{Activité cellulaire.}

$R N A / D N A$ (fig. $6 c$ ). - Le rapport $\mathrm{H}$ augmente de 3,47à 3,67 quand le poids du foie augmente de 3,9 à $9,4 \mathrm{~g}$; il redescend ensuite et se stabilise vers 3,2 . L,e rapport $G$ garde une valeur s'écartant peu de 3,4 pendant toute la période étudiée.

Azote protéiquel $D N A$ (fig. $6 d$ ). - Le rapport $\mathrm{H}$ augmente rapidement de 3,6 à 4,7 quand le poids du foie augmente de 3,9 à $\mathrm{I} 3 \mathrm{~g}$. Il n'augmente plus ensuite que très lentement. Le rapport $G$ ne subit pas une brusque augmentation suivie d'un ralentissement, mais au contraire une augmentation régulière ; comme dans le cas de l'intestin grêle, il devient supérieur au rapport $H$ correspondant.

\section{DISCUSSION}

\section{$\mathrm{A}-$ Choix des lots}

La croissance des animaux des lots analysés, tant avec le régime $\mathrm{H}$ qu'avec le régime $G$ correspond en général à la croissance moyenne observée sur un grand nombre d'animaux; une exception toutefois : le lot $\mathrm{G}_{3}$ est composé d'animaux ayant présenté une croissance plus faible que la moyenne, les animaux de ce lot auraient dû peser, au lieu de $205 \mathrm{~g}$, environ $230 \mathrm{~g}$.

\section{$\mathrm{B}$ - Considérations générales}

Les animaux qui reçoivent les protéines de mauvaise qualité ont un moins grand appétit (fig. 2). Les effets d'une alimentation à base de gluten de blé, que nous avons étudiés, sont donc la somme : 
Io d'une carence des protéines en certains acides aminés indispensables: lysine et tryptophane.

$2^{\circ}$ d'une réduction de la consommation totale des protéines.

$3^{\circ}$ d'une réduction de la consommation d'énergie.

Avec la méthode utilisée, il n'est pas possible de déterminer la part qui revient à chacune de ces trois causes. D'autre part, comme il en avait déjà été discuté dans une précédente publication, des organes comme le foie ou l'intestin grêle, ou un ensemble de tissus comme ce que nous avons appelé "carcasse ", sont constitués de tissus variés (musculaires, osseux, conjonctifs, épithéliaux, etc.). La méthode utilisée ne permet pas de déterminer la part revenant à chacun d'eux.

Dans ce qui suit, compte tenu des conventions adoptées dans l'introduction, les expressions :

Quantité de DNA

Rapport poids frais/DNA

RNA/DNA et azote/INA

seront remplacées respectivement par :

Nombre de cellules $=\mathrm{N}=k \times \mathrm{DNA}$
Taille de cellule $=\frac{\text { Poids frais }}{\mathrm{N}}=p$
Quantité de RNA par cellule et quantité d'azote par cellule

Carcasse

Le nombre de cellules contenues dans les carcasses des animaux du lot $\mathrm{H}_{5}$ est légèrement inférieur au nombre de cellules contenues dans les carcasses des animaux $\mathrm{H}_{4}$. I1 semble peu probable que cette diminution soit 1'expression d'une réalité physiologique relative au vieillissement, mais plutôt l'effet d'une variabilité génétique liée à l'hétérogénéité de la souche de rats utilisés. Toutefois, les influences possibles d'autres facteurs de variabilité (saison, environnement, etc.) ne doivent pas être écartées.

a) Infuence des protéines alimentaires sur le nombre de cellules contenues dans des carcasses comparées à poids égal.

De 1'analyse des résultats, il ressort que le nombre de cellules contenues dans des carcasses d'animaux normalement alimentés est une fonction du poids de cellesci ; il apparaît aussi qu'à partir d'un certain stade de la croissance (après sevrage), cette fonction peut êrre assimilée à une hyperbole :

$$
\text { Nombre de cellules }=\frac{a \times \text { poids frais }}{b \times \text { poids frais }+c}
$$

$a$ étant un coefficient dépendant des unités choisies, $b$ et $c$ étant des paramètres.

Le passage d'un régime riche à un régime pauvre est suivi d'une période au cours de laquelle la multiplication cellulaire est inhibée ; la croissance pondérale, devenue faible, est due au seul grandissement cellulaire. Cette période de transition 
étant achevée, le nombre de cellules augmente à nouveau en fonction du poids de 1'animal, suivant une hyperbole du même type que la précédente, mais différente quant à ses paramètres, ceux-ci étant tels que le retard pris vis-à-vis des animaux bien alimentés peut être en partie comblé, mais en partie seulement.

La régularité des arcs de courbe représentant les variations de la quantité de noyaux, tant en fonction du poids que de l'âge (et en conséquence la régularité des arcs de courbe représentant la variation de la taille des cellules en fonction des mêmes variables), est remarquable, si l'on considère la grande diversité des tissus composant la carcasse. Le fait que l'on ne constate pas de "décrochements " soudains est le signe que le développement de l'organisme est le résultat d'une évolution harmonieuse de 1'ensemble de ses constituants et qu'aucun accident (arrêt de la croissance d'un tissu, déclenchement de la croissance d'un autre, apparition de polyplö̈die) ne vient brusquement en briser le rythme.

Ceci, tout aussi vrai pour l'intestin grêle, est un peư moins évident pour le foie.

Dans la présente étude, les animaux ont été soumis au régime pauvre à un stade précoce de la croissance ( 4 semaines, $70 \mathrm{~g}$ ), et la période de transition s'est étendue sur plus de deux semaines. La durée de cette dernière devient de plus en plus brève et finalement devient nulle quand le passage d'un régime à l'autre a lieu à un stade de plus en plus tardif de la croissance (DURAND, non publié). Ceci peut conduire à penser que les animaux, qui ont accumulé la plus grande part du capital cellulaire fixé par leur capacité génétique, deviennent insensibles à des carences en lysine et en tryptophane et peuvent dès lors être considérés comme adultes. En pratique, et avec la souche utilisée, ce stade adulte correspond aux animaux du lot $\mathrm{H}_{4}$ ( $\mathrm{I} 7 \mathrm{se}$ maines, $400 \mathrm{~g}$ ), puisque la quantité de IJNA contenue dans les carcasses des animaux de ce lot et celle contenue dans les carcasses des animaux du lot $\mathrm{H}_{5}$ (fig. 4 a) ne sont pas sensiblement différentes. Une telle définition de l'état adulte soulève le problème suivant : étant donné que les animaux $G$ atteignent moins vite leur capital cellulaire maximal, doit-on en conclure que le fait d'avoir reçu une alimentation de médiocre qualité retarde l'arrivée à l'âge adulte et que la jeunesse s'en trouve en quelque sorte prolongée?

Les travaux de plusieurs auteurs (cités par ANDREW, I960) laissent penser qu'un allongement de la période de croissance dû̀ à une réduction de la consommation alimentaire favorise l'allongement de la durée de vie des animaux. En va-t-il de même lorsque l'allongement de la période de croissance est dû à la médiocrité des protéines alimentaires? Aucune donnée ne permet actuellement de prévoir quel peut en être le retentissement sur les états physiologiques futurs de l'animal.

b) Étude de l'influence relative de l'augmentation du nombre et de la taille des cellules sur la croissance des carcasses $H$ et $G$, comparées à poids égal.

Soit $\mathrm{P}$ le poids frais d'un tissu (ou d'un ensemble de tissus), N le nombre de cellules dont il est constitué, $p$ la taille de ces cellules. On a, par définition :

ou

$$
\mathrm{P}=\mathrm{N} \times p
$$

on peut écrire

$$
\begin{aligned}
\mathrm{P} & =k \mathrm{DNA} \times p \\
\frac{d \mathrm{P}}{\mathrm{P}} & =\frac{d(\mathrm{DNA})}{\mathrm{DNA}}+\frac{d p}{p}
\end{aligned}
$$


Il est évidemment impossible de mesurer des variations du DNA et de $p$ pour des variations de poids $d \mathrm{P}$ arbitrairement petites; aussi on ne peut utiliser la relation que sous la forme :

$$
\frac{\Delta \mathrm{P}}{\mathrm{P}}=\frac{\Delta(\mathrm{DNA})}{\mathrm{DNA}}+\frac{\Delta p}{p}
$$

Cette expression peut être traduite ainsi :

" La variation relative du poids d'un tissu (ou d'un ensemble de tissus) autour d'un poids donné est égale à la somme des variations relatives concomitantes du nombre et de la taille des cellules dont il est constitué. "

\section{Calcul des éléments de la relation (4).}

Soient $\mathrm{P}_{1}, \mathrm{DNA}_{1}$ et $p_{1}$, les caractéristiques d'un tissu à un moment donné ; sous l'effet d'une variation de poids $P$, ces caractéristiques deviennent $P_{2}, D N A_{2}, p_{2}$.

\section{TABLEAU 6}

\section{Carcasse}

La variation relative du poids de la carcasse, somme des variations relatives concomitantes du nombre et de la taille des cellules dont elle est constituée

\begin{tabular}{|c|c|c|c|c|c|c|c|}
\hline $\begin{array}{l}\text { Périodes . . . . . . . } \\
\text { Temps (semaines) . . } \\
\text { Poids moyen (g).... }\end{array}$ & $\begin{array}{l}\text { I } \\
3 \text { à } 4 \\
46\end{array}$ & $\begin{array}{l}1_{h} \\
4 \text { à } 5 \\
73\end{array}$ & $\begin{array}{l}\mathrm{II}_{h} \\
5 \text { à } 7,5 \\
129\end{array}$ & $\begin{array}{c}\mathrm{III}_{h} \\
7,5 \stackrel{\mathrm{a}}{ } 10 \\
210\end{array}$ & $\begin{array}{c}\mathrm{IV}_{h} \\
10 \stackrel{\mathrm{a}}{10} 17 \\
305\end{array}$ & $\begin{array}{c}\mathrm{V}_{h} \\
17 \stackrel{\mathrm{a}}{40} \\
405\end{array}$ & \\
\hline$\frac{\Delta \mathrm{P}}{\mathrm{P}} \times 10^{2} \ldots \cdots \cdot$ & 40 & 44 & $6 \mathrm{t}$ & 40 & 35 & 22 & Régime $\mathrm{H}$ \\
\hline$\frac{\Delta(\mathrm{DNA})}{\mathrm{DNA}} \times 10^{2} \ldots$ & 32 & 32 & 34 & 18 & 17 & -2 & \\
\hline$\frac{\Delta p}{p} \times 10^{2} \ldots \ldots \ldots$ & 17 & 11 & 29 & 23 & 18 & 24 & \\
\hline
\end{tabular}

\begin{tabular}{|c|c|c|c|c|c|}
\hline $\begin{array}{l}\text { Périodes } . . \ldots \ldots \ldots \ldots \ldots \\
\text { Temps (semaines) } \ldots \ldots \ldots \ldots \ldots \\
\text { Poids moyen }(g) \ldots \ldots \ldots \ldots \ldots\end{array}$ & $\begin{array}{l}\mathrm{I}_{g} \\
4 \text { à } 7,5 \\
74\end{array}$ & $\begin{array}{l}\mathrm{II}_{g} \\
7,5 \text { à } 10 \\
113\end{array}$ & $\begin{array}{l}\mathrm{III}_{g} \\
10 \text { à } 17 \\
160\end{array}$ & $\begin{array}{l}\mathrm{IV}_{g} \\
17 \text { à } 40 \\
294\end{array}$ & \\
\hline$\frac{\Delta P}{P} \times 10^{2} \ldots \ldots \ldots \ldots \ldots \ldots \ldots$ & 45 & 42 & 29 & 76 & Régime $\mathrm{G}$ \\
\hline$\frac{\Delta(\mathrm{DNA})}{\mathrm{DNA}} \times 10^{2} \ldots \ldots \ldots \ldots \ldots$ & -2 & 28 & 19 & 40 & \\
\hline$\frac{\Delta p}{p} \times 10^{2} \ldots \ldots \ldots \ldots \ldots \ldots \ldots$ & 46 & 13 & 10 & 38 & \\
\hline
\end{tabular}


I1 vient alors :

$$
\begin{array}{lrl}
\Delta \mathrm{P}=\mathrm{P}_{2}-\mathrm{P}_{1} & \mathrm{P}=\frac{\mathrm{P}_{2}+\mathrm{P}_{1}}{2} \\
\Delta(\mathrm{DNA})=\mathrm{DNA}_{2}-\mathrm{DNA}_{1} & \mathrm{DNA}=\frac{\mathrm{DNA}_{2}+\mathrm{DNA}_{1}}{2} \\
\Delta p=p_{2}-p_{1} & p=\frac{p_{2}+p_{1}}{2}
\end{array}
$$

Les calculs concernant respectivement les carcasses des rats $\mathrm{H}$ et $\mathrm{G}$ sont rassemblés dans le tableau 6. Les importances relatives de la division cellulaire (exprimées en p. Ioo du gain de poids relatif), en fonction du poids de carcasse, sont représentées sur les figures $7 a$ et $7 b$.

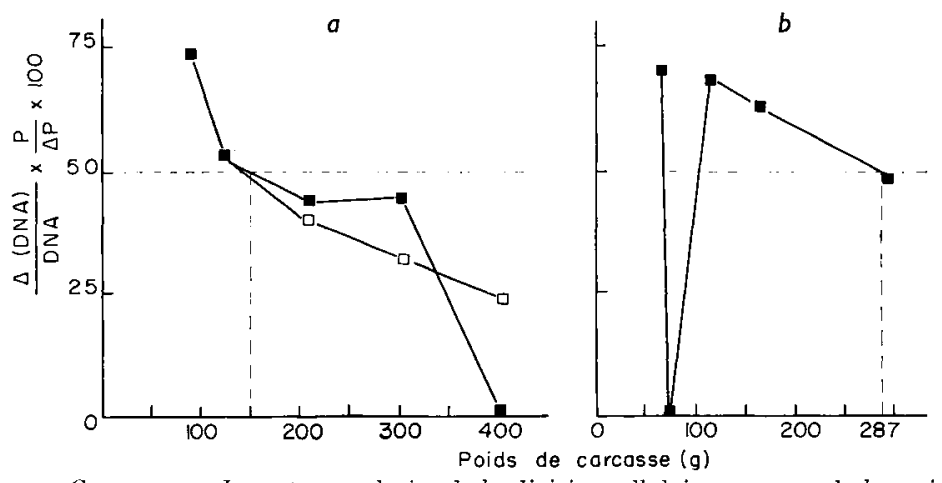

FIG. 7. - Carcasse. - Importance relative de la division cellulaire au cours de la croissance en fonciion du poids de la carcasse

a) rats "Farine de Hareng" a points observés $\square$ points théoriques

b) rats "Gluten"

I1 apparaît clairement que : dans le cas $\mathrm{H}$, l'augmentation du nombre de cellules est le facteur le plus important de la croissance jusqu'à ce que les carcasses pèsent $145 \mathrm{~g}$ (rats de $\mathrm{I} 7 \mathrm{~g} \mathrm{~g}$, âgés de 7 semaines). Au-dełà, le fait que l'influence de l'augmentation du nombre de cellules présente un palier suivi d'une chute brutale est dû à l'anomalie qui existe en ce qui concerne les quantités comparées de DNA contenues dans les carcasses des animaux $\mathrm{H}_{4}$ et $\mathrm{H}_{5}$. Il est probable que la réalité est proche de la courbe théorique obtenue à partir de l'équation dérivée de l'équation (I) qui fournit l'expression :

$$
\frac{\mathrm{I}}{\mathrm{DNA}} \times \frac{d(\mathrm{DNA})}{d \mathrm{P}}=\frac{107,3}{\mathrm{P}(0,74 \mathrm{P}+\mathrm{I07,3})} .
$$

Cette courbe théorique indique que, dans le gain de poids résiduel d'animaux en fin de croissance, la multiplication cellulaire interviendrait encore pour environ 24 p. 100.

- dans le cas des animaux $\mathrm{G}$, la période d'inhibition mise à part, l'augmentation du nombre de cellules est le facteur le plus important de la croissance jusqu'à ce que les carcasses des animaux pèsent $290 \mathrm{~g}$ environ (rats de $320 \mathrm{~g}$, âgés de 20 semaines). 
c) L'âge et la taille des cellules.

La taille des cellules de la carcasse semble assez indépendante du régime alimentaire, donc de la vitesse de croissance, et semblerait être une caractéristique liée à l'âge (fig. 8). On peut remarquer que, dans le cas le moins favorable qui est celui des lots $\mathrm{H}_{4}$ et $\mathrm{G}_{3}$ âgés l'un et l'autre de $\mathrm{I} 7$ semaines, la différence entre la taille des cellules n'est que de 9 p. Ioo alors que le poids des carcasses varie du simple au double.

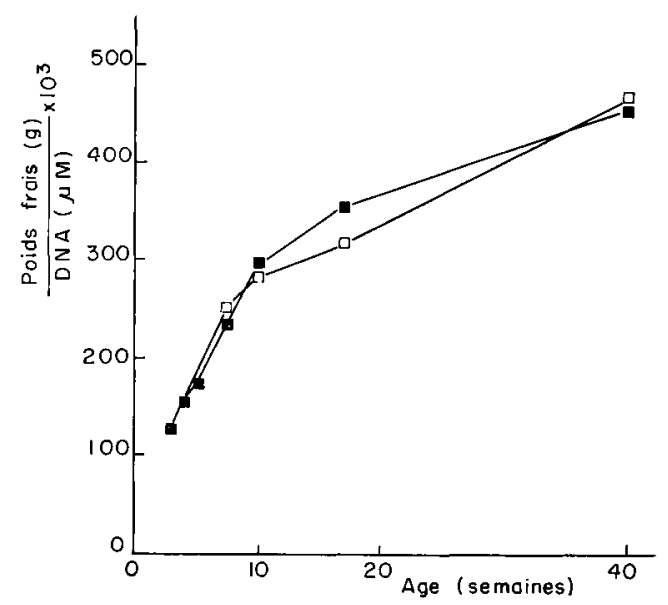

Fig. 8. - Carcasse. - Évoluiton de la taille des cellules (rapport Poids frais/DNA) en fonction de l'âge des animaux.

- rats " Farine de Hareng " $\square$ rats "Gluten "

d) La teneur des carcasses en azote et la multiplication cellulaire.

En limitant l'apport d'acides aminés indispensables, on limite la synthèse des protéines, donc la synthèse du DNA (DOUdNEy, I96r ; Pritchard et LARK, I964; LEGROS et BRACHET, I965; TAYLOR, I965), mais on constate que le ralentissement de la synthèse des protéines et celui du DNA ne sont pas proportionnels, puisque le rapport protéines/DNA G est plus grand que le rapport $\mathrm{H}$ correspondant. Faut-i1 en penser que d'autres facteurs secondaires à la carence en lysine et en tryptophane interviennent pour diminuer le nombre des mitoses, en particulier la modification du métabolisme énergétique (fig. 3 b) ? L'étude de PROP et HENDRIX (I965), à propos de l'action de l'insuline sur le taux mitotique, vient à l'appui de cette hypothèse.

\section{Intestin grêle}

Comme il a déjà été signalé, le poids frais de l'intestin grêle du lot $\mathrm{G}_{4}$ est exceptionnellement faible. De même, la quantité de RNA par cellule des organes de ce lot n'est sans doute pas représentative.

L'épithélium de l'intestin grêle du rat est soumis à un renouvellement rapide, de l'ordre de quelques dizaines d'heures (LEBLOND et STEVENS, I948). La vitesse de renouvellement de l'épithélium intestinal peut être modifiée par l'alimentation (Hooper et Blair, I958; Munro et Goldberg, I963). 
Il s'ensuit que le nombre de noyaux en phase $S$ peut être également modifié par 1'alimentation. S'il en était ainsi, la quantité moyenne de DNA par noyau pourrait ne pas être la même dans les deux cas, $H$ et $G$; notre méthode de comparaison risquerait d'être en défaut. En fait, il n'en est rien, en effet, la prolifération cellulaire de 1'épithélium intestinal est limitée aux cryptes de I,IEBERKÜHN (LEBLOND et STEVENS, r948). Il a été montré, d'autre part, que $35 \mathrm{p}$. Ioo des cellules de ces cryptes se trouvaient à chaque instant en phase S (CAIRNIE et al.,I965). On peut admettre que tout se passe comme si $17,5 \mathrm{p}$. roo des cellules des cryptes étaient tétraploïdes. Or, les cellules des cryptes ne représentent qu'une faible partie, inférieure à Io p. Ioo, du nombre des cellules totales de l'organe (Vodovar, communication personnelle). En conséquence, le fait que la variation du régime alimentaire entraîne une variation de la vitesse de renouvellement de l'épithélium intestinal ne saurait avoir une influence appréciable sur la teneur moyenne en DNA par cellule.

Compte tenu de ces remarques, il apparaît que :

$I^{\circ} I_{1}$ e poids frais de l'intestin ne dépend que du poids de l'animal et il n'augmente plus que très lentement dès que celui-ci atteint $200 \mathrm{~g}$.

$2^{\circ}$ La taille des cellules de l'organe est caractéristique du régime, sans que l’on puisse dire si la responsabilité en incombe aux seules protéines ou à l'ensemble du régime. En effet, ComBE et al. (I965) trouvaient, avec un régime contenant $20 \mathrm{p}$. Ioo de caséine, un nombre et une taille de cellules très comparables à ce qui a été mis en évidence à propos des rats recevant du gluten de blé. Avec un tel régime, la qualité des protéines ne pouvait être mise en cause.

$3^{\circ} \mathrm{A}$ partir du moment où les cellules ont atteint la taille caractéristique du régime, celle-ci demeure remarquablement stable. Par conséquent, la croissance est due exclusivement à l'augmentation du nombre de cellules.

\section{Foie}

I1 est connu qu'une forte proportion des noyaux du foie sont polyploïdes; de plus, le taux de polyploïdie peut varier sous l'influence de facteurs intrinsèques et extrinsèques, en particulier l'âge (Thomson et al., I953 ; Fukuda et Sibatani, I953; ENESCO et LEBLOND, I962) et l'alimentation (KARANDE et INAMDAR, I964). La mesure des variations des quantités de DNA ne permet donc plus de mesurer le nombre de cellules que de façon fort imprécise. Il est difficile de tirer des conclusions exactes sur l'incidence de l'augmentation du nombre des cellules et de leur grandissement sur la croissance de foies soumis à différentes conditions alimentaires. Il faudrait au préalable déterminer la quantité de DNA moyenne par noyau des différents lots étudiés. Certains auteurs (KARANDE et INAMDAR, I964), qui ont étudié l'influence de l'alimentation sur la polyploïdie du foie, ont trouvé qu'une alimentation protéique insuffisante soit en quantité, soit en qualité agissait en augmentant la proportion de noyaux diploïdes (au détriment des noyaux tétra- et octoploïdes), donc en diminuant la quantité moyenne de DNA par noyau. D'autres auteurs (UMANA, I965) ont trouvé le contraire; d'autres encore n'ont pas trouvé de modifications notables (Thomson et al., I953). Le problème reste posé.

Quoi qu'il en soit, il apparaît que :

Io Quel que soit le régime alimentaire, la croissance du foie dure aussilongtemps 
que la croissance de l'animal, et elle est toujours due pour la plus grande part à l'augmentation du nombre des cellules.

$2^{0}$ A poids d'animal égal, le foie de l'animal qui reçoit les protéines de mauvaise qualité est plus petit (Io p. IOo) et moins riche en protéines.

$3^{\circ}$ Comparés à poids égal, les foies $G$ possèdent un nombre de cellules à peu près égal à celui des foies $H$, tant que le poids vif des animaux ne dépasse pas $200 \mathrm{~g}$. Au-delà, il semble qu'ils en contiennent moins.

Reçu pour publication en mars 1966.

\section{SUMMARY}

GROWTH OF TISSUES IN THE RAT AND QUALITY OF PROTEIN IN THE DIET;

INFLUENCE ON NUMBER AND SIZE OF CELLS

Groups of male rats aged 4 to 40 weeks were given, from 4 weeks of age $(7 \circ \mathrm{g})$ a diet supplying protein of good quality, Norwegian herringmeal, or one supplying protein of poor quality, wheat gluten. The two diets were equal in energy value, and both had I6 p. roo crude protein $(\mathrm{N} \times 6,25)$. The rats given herringmeal (Diet H) grew normally, $5,5 \mathrm{~g}$ daily ; those getting wheat gluten (diet $\mathrm{G}$ ), deficient in lysine and tryptophan had reduced rate of gain, $\mathrm{x}, 5 \mathrm{~g}$ daily.

Growth of the carcass (body of the animal less liver and small and large intestines), of small intestine and of liver were studied by measuring variations in :

- Deoxyribonucleic acid (DNA) content, the amount of which is proportional to the number of nuclei, or by extension, the number of "cells";

- The ratio of weight to DNA proportional to the weight and thus to the "size of cells "

- Some aspects of cellular activity, expressed by changes in ratios of ribonucleic acid (RNA) and of protein to DNA.

From analysis of results the following points emerge :

a) Carcass. - Normal animals : from the age of 4 weeks the number of cells of the carcass may be considered as a hyperbolic function of its weight. The increase in the number of cells is the greatest factor of growth until the carcass weighs $145 \mathrm{~g}$ (rats weighing $170 \mathrm{~g}$, aged 7 weeks, the time of puberty) Thereafter the increase in size of cells becomes the more important factor. The amount of RNA per cell is greatest when the animals weigh between 100 and $200 \mathrm{~g}$, aged 5 to 7 weeks. - Deprived animals: during the 2 or 3 weeks after starting on diet G, increase in the number of cells is inhibited. After that, the number increases once again as a function of weight of the carcass, following a hyperbola different from the preceding one; the setback during the period of inhibition does not seem to be able to be completely overcome. Except during the period of inhibition, increase in the number of cells is the most important factor of growth until the carcases of the animals weight about $290 \mathrm{~g}$ (rats of $320 \mathrm{~g}$, aged 20 weeks). The amount of RNA per cell remains always close to the value in animals aged 4 weeks. The size of the cell is independent of the diet and seems to be a characteristic related to age.

b) Small intestine. - The growth of the organ does not depend on the diet but only on weight of the animal, and becomes very small when the animal reaches $200 \mathrm{~g}$. Size of cells is characteristic of the diet and is greater on diet G (I 2 per cent). As soon as this characteristic size is reached, growth of the organ is due exclusively to increase in the number of cells. The amount of RNA per cell is less when the animals are deprived.

c) Liver. - At equal bodyweight the liver of the deprived animal is smaller (Io per cent), and contains less protein than the liver of the normal animal. The liver of the deprived animal has fewer cells than a liver of the same weight from a normal animal, but whatever the diet, growth of the organ goes on as long as the animal is growing, and is always due for the most part to increase in the number of cells. The amount of RNA per cell is at a maximum at 7 weeks of age in normal animals ; in deprived animals it remains close to the value found in animals 4 weeks old. 


\section{RÉFÉRENCES BIBLIOGRAPHIQUES}

ANDREW A., I960. Growth and the aging process in : Fundamenlal aspects of normal and malignarl growth. Ed. W. W. Nowinsky, 952-972, Elsevier publishing company.

Boivin A., Vendrely R., Vendrely C., I948. L'acide désoxyribonuclúique du noyau cellulaire dépositaire des caractères héréditaires; arguments d'ordre analytique. C. R. Acad. Sci., 226, ro6r-1062.

Cairnie A. B., Lamerton I. F., Steed G. G., I965. Cell proliferation studies in the epithelium of the rat. Exp. Cell Res., 39, 528-538.

Combe E., Penot F., Chardier II., Sacouet F., r965. Métabolisme du rat germ-free. Ann. Biol. anim. Bioch. Biophys., 5, I89-206.

DOUdney C. O., I96r. Recovery of nucleic acid synthesis in bacteria after amino-acid starvation. Biochem. Biophys. Res. Comm., 5, 405-409.

Durand G. A., Favconseat G., Pexot E., rg65 a. Etude biochimique de la croissance de l'intestin grêle, du foie et de la carcasse du rat ; rôles respectifs de la multiplication et du grandissement cellulaires. Ann. Biol. anim. Bioch. Biophys., 5, $163-187$.

Durani) G. A., Fauconneau G., Penot li., ig65 b. Influence de l'âge et du régime alimentaire sur la teneur en acides nucléiques et en protéines de la carcasse du Rat blance en croissance. C. R. Acad. Sci., 260, $7002-7005$.

F.NESCO M., LEBLOND C. P., I962. Increase in cell number as a factor in the growth of the organs and tissues of the young male rat. J. Embryol. Exp. Morph., 10, Part. 4, 530-562.

Fukuda M., Sibatani A., I953. Relation between the body weight and the average DNA content of liver nuclei in postmatal growth of the rat. Lixp. Cell. Res., 4, $23^{t-2} 38$.

HENRY Y., Rérat A., I963. Étude de l'ingestion spontr ée d'éléments énergétiques et de protéines chez le rat en croissance par la méthode du libre choix. Ann. Biol. anim. Bioch. Biophys., 3, 103-II 7 .

HoOper C. S., BLAIR M., i 958. The effect of starvation on epithelial renewal in the rat duodenum. Exp. Cell Res., 14, 175-I8I.

KARANDE A. A., INAMDAR N. B., ig 1 . Observations on liver polyploïdie of rat under different dietetic states. Indian J. Lxp. Biol., 2, $13^{8-1} 42$.

Lerloni) C. P., Srzvens C. L., I948. The constant renewal of the intestinal epithelium on the albino rat. Anat. Rec., 100, 357-378.

Iegros F., BRACiet J., I065. Effets de la puromycine sur la mitose, la synthèse des protéines et celle du DNA au cours de la segmentation de l'xuf de Batracien. J. Embryol. Exp. Morph., 13, Part. 2, I95-206.

Mitciele H. H., 1947. Protein utilization by the adult rat : the lysine requirement. Arch. Biochem., 12, 293-300.

MunRo II. N., GoldBerg I). M., Ig64. The effect of protein intale on the protein and nucleic arid metabolism of the intestinal mucosal cell. In : The role of the gastrointestinal tract in protein metabolism. lid. MUNRO H. N. Colloguium of the Concil for International Organization of Iled. Sci. Blackwell, Oxford.

PRITCILARD R. II., LARK K. (i., I964. Induction of replication by thymine starvation at the chromosome origin in Escherichia coli. J. Mol. Biol., 9, 288-307.

Prop F. J., HENDRIX S. E., 1965. Lffect of insulin on mitotic rate in organ cultures of total mammary glands of the mouse. Exp. Cell Res., 40, $277-281$.

Ranilotra G. S., Jolinson 13. C., I965. Jiffect of feeding different anino acid diets on growth rate and nitrogen retention of weanling rats. Proc. Soc. Exp. Biol. Met., 118, i 197-1 201 .

Rogers Q. R., Harper A. E., I965. Amino acid diets and maximal growth in the rat. $/ . N_{u l r}, \mathbf{8 7}^{\mathbf{7}}, \mathbf{2 6} \mathbf{7}^{-}$ 273.

TAYLOR F. W., 1965. Control of DNA synthesis in mammalian cells in culture. Exp.Cell Res., 40, 316-332.

Thomson R. Y., Neagy F. C., Hutchinson W. C., Davidson J. N., 1953. DNA content of the rat cell nucleus and its use in expressing the results of tissue analysis ; with particular reference to the composition of liver tissue. Biochem. J., 53, 460-474. 